\title{
Collusion in the Provision of Foreign Aid: The Rise of Lead Donorship
}

\author{
Martin C. Steinwand*
}

January 22, 2015

\begin{abstract}
Donor proliferation and the fragmentation of aid delivery is an important problem besetting foreign aid policy. Yet, existing works have failed to explain under which circumstances donors allow an individual country to become a lead donor with an unrivaled sphere of influence. We fill this gap by analyzing lead donorship as a specific form of coordination wherein donors collude in the provision of aid in order to realize private gains. Employing an event history analysis on bilateral aid data covering the period 1970-2010, we find that lead donorship becomes more likely a) when donor countries expect economic benefits (such as oil exports and exports markets for goods) and b) when donor and recipient have a shared history of colonialism. Conversely, the presence of natural disasters and civil war discourages lead donorship, promoting donor fragmentation instead.
\end{abstract}

*Department of Political Science, Stony Brook University, martin.steinwand@stonybrook.edu 


\section{Introduction}

Donor proliferation and the fragmentation of aid delivery is an important problem besetting foreign aid policy. Scholars have shown that the large increase in the number of state and non-state actors active in providing developmental aid can have serious negative consequences for aid efficacy (Djankov et al. 2009), and political institutions (Knack and Rahman 2007). ${ }^{1}$ Accordingly, academics and practitioners alike have spent much energy to raise awareness for the need for better donor coordination, and to examine the apparent lack of reactions to these calls (OECD 2005; Easterly 2007). In comparison, scholars have paid very little attention to a surprisingly large number of cases in which aid delivery actually is not fragmented. A study by the OECD on 'aid orphans' shows that there exist numerous countries that only have a handful of donors and are severely under-served with Official Development Aid (ODA) (Ericsson and Steensen 2014). Similarly, about twenty percent of all countries that receive ODA through bilateral channels consistently have most of their aid provided by only a single top donor (Steinwand 2013). The processes that drive over-engagement of donors in one set of countries cannot be separated from the question why some countries are aid orphans and others have a lead donor. There exist a few pioneering works that look at lead donorship. They characterize the processes that give rise to lead donorship as a competition between donors for influence. Top aid contributors try to outbid others (Lebovic 2005) or seek to reign in competition by colluding to form spheres of influence (Steinwand 2013). In this paper, we explore under which circumstances lead donorship arises. Understanding variation at the end of the spectrum where aid provision is highly concentrated can help us shed light on the causes of donor fragmentation as well.

To gauge the relevance of fragmented versus concentrated modes of aid delivery consider the examples of Mozambique and Madagascar. Mozambique faced major challenges after

\footnotetext{
${ }^{1}$ But see (Steinwand and Gutting 2012) for positive effects of fragmentation on aid volatility and political stability.
} 
the end of its 16 year civil war in 1992. Economic output was on average just above $\$ 1$ per person and day. The country's infrastructure lay in ruins, and immediate humanitarian needs were wide ranging. The international donor community responded with a massive aid effort. Initial commitments surpassed $\$ 1$ billion a year, amounting to 18 percent of the country's GDP. This outpouring of aid also meant a proliferation of active donors and nongovernmental organizations. Aid to Mozambique became very fragmented and has stayed so to the present. The Herfindahl-Hirshman index (HHI), a common measure of donor concentration on a 0 to 1 scale ( 0 denoting perfect fragmentation), has been around 0.09 since 1992, compared to an average of 0.30 for all aid recipient countries during that period. Unlike other African countries, the former colonial power Portugal never had the ability to provide support or exert ongoing influence after Mozambique reached independence in 1975.

A similar country is Madagascar. Madagascar is an island opposite the Mozambican coast in the Indian Ocean. As in Mozambique, the end of the Cold War had profound effects on the political system in Madagascar. Sixteen years of autocratic rule by president Ratsiraka were followed by reforms establishing multiparty competition. Although Madagascar had not experienced the destruction of civil war, its economy was stagnating, with economic output at about $\$ 2.3$ per person and day.

Despite the economic needs and the promise for reform that Madagascar had shown in the 1990s, donors reacted very differently than in Mozambique. Development aid provision largely remained in the hands of France, the historic colonial power. Shouldering around half of all aid payments, France has continued as lead donor from 1992 to the present. Overall aid levels remain low, at less than 4 percent of GDP. The OECD lists Madagascar as an 'aid orphan' for all 7 years it has studied (2006-2012), alongside only two other countries, Guinea and Nepal (Ericsson and Steensen 2014). ${ }^{2}$

\footnotetext{
${ }^{2}$ Aid orphan status is determined on the basis of aid per capita, UNDP TRAC-1 allocations, Collier/Dollar poverty efficient allocations, and IDA 15 performance-based allocations.
} 
The comparison between Mozambique and Madagascar reveals large differences in donor engagement, accompanied by vastly different aid delivery structures and results. Aid to Mozambique reached very highly levels and in the course of this became highly fragmented. In Madagascar aid flows never picked up and aid delivery remained centralized in the hands of France as lead donor. The international donor community engaged at very different levels although both countries were undergoing democratization processes in the crucial years after the end of the cold war. One important explanation for this difference lies in the historic role that France has played as former colonial power and lead donor. We need to understand why lead donorship in Madagascar persisted, whereas no single donor was able to take a leadership role in Mozambique.

While the concept of aid orphans has important implications for policy appeal, in this paper we concentrate on exploring the determinants of lead donorship. The OECD Development Assistance Comittee (DAC) only provides data on aid orphans for the last seven years, and the concept has not matured beyond an empirical indicator. In contrast, existing works on lead donorship provide a theoretical framework that focuses on the private benefits of lead donorship (Lebovic 2005) and tie lead donorship explicitly to donor coordination (Steinwand 2013). We draw on this framework to develop hypotheses about the sources of lead donorship onset and duration.

The premise we build on is that lead donorship cannot be sustained in the long run if other donors have incentives to provide large amounts of aid themselves. Steinwand (2013) shows empirically that long-term lead donorship is associated with coordinated donor behavior, where top donor allocation decisions induce other donors to reduce their own aid contributions. He argues that lead donorship represents a special form of coordination, where the top donor receives private benefits from its position while it colludes with other donors to leave this position unchallenged.

We identify stake holders such as implementing bureaucracies, aid agencies, and top 
level government figures on both the recipient and donor sides, and explore their motives and capabilities regarding lead donorship coordination. Our analysis highlights the role of colonial history and the passage of time since independence for a) the ability of donors to coordinate among themselves and b) the capacity of recipient bureaucracies to extract themselves from exclusive relationships to a top donor. Economic opportunities and the role of oil exports and imports from donor countries add to the economic incentives that donors have to collude.

Our work contributes to the growing literature on donor fragmentation and coordination. Despite the great policy relevance of fragmentation for economic growth (Djankov et al. 2009), government institutions (Knack and Rahman 2007) and political stability (Steinwand and Gutting 2012), there is still little understanding of the incentive structures that prevent donors from overcoming fragmentation. Studying coordination in the context of lead donorship points to private benefits and side payments as central tools for achieving coordinated outcomes. This raises important questions whether all forms of coordination between donors are beneficial from a recipient country perspective and for purposes of welfare maximization. The lack of coordination in developmental aid may result in friction losses, such as program duplication and increased administrative burdens for recipient bureaucracies. This may lead to reduced aid effectiveness. On the other hand, when donors carve out exclusive spheres of influence, recipient governments forfeit valuable rents and overall aid levels can fall.

In the empirical analysis, we explore empirical patterns of lead donorship onset, using event history analysis covering the years 1970-2010, and 142 recipient countries of bilateral official development aid (ODA). We find that colonial history and donor economic interests strongly increase the chances of lead donorship onset and that donor coordination is a dynamic process that unfolds over long time horizons. 


\section{Theoretical Considerations}

In the following, we develop our argument about the origins of lead donorship. To predict when lead donorship occurs, we need to understand what drives the top aid contributor to provide the most aid, but also why other donors do not give as much. Steinwand (2013) argues that there are two scenarios in which the answers to these questions fundamentally differ. The key distinction lies in the motives why donors give aid. First, donors may genuinely care about developmental outcomes such as reductions in child mortality, educational achievement, and nutritional security, to name but a few common measures of human development. Such goals do have classic public good properties from a donor perspective, since they are non-excludable (no donor can be kept from enjoying development success irrespective of its own contribution) and non-rivalrous in consumption (enjoyment does not diminish with larger numbers of donors). Drawing on a classic argument by Olson and Zeckhauser (1966), asymmetries in aid provision result when the top donor has lower marginal costs/greater marginal benefits from providing the public good, and everybody else is freeriding on the top donor's efforts. Lead donorship in the provision of public goods therefore arises without any coordination between donors.

Second, donors can give aid for 'selfish' reasons. One of the most prominent academic debates on foreign aid has sought to entangle donor motives from recipient country needs. Starting with McKinlay and Little (1977, 1978); McKinley and Little (1979) in the 1970s, this literature has identified a large number of donor interests as potential drivers of aid policies. The most important goals include efforts to secure diplomatic influence, access to strategic raw materials, and promotion of donor export industries. ${ }^{3}$ In this case, aid has private good properties. Lebovic (2005) explores donor motives for providing aid and for

\footnotetext{
${ }^{3}$ Just a few examples from a large literature are Morgenthau (1962); Dreher et al. (forthcoming 2015) for diplomatic influence, Lancaster (2007, p. 116f) for access to raw materials, and Younas (2008) for export promotion. A good overview can be found in Wright and Winters (2010). Although we concentrate here on bilateral ODA, similar motives also affect aid allocations by international financial institutions (Kilby 2013).
} 
taking the top donor spot. He finds that private interests such as export promotion and strategic influence account for the propensity to act as top donor, apart from the decision of how much aid to actually allocate. Lebovic does not consider the possibility that donors might compete for the top spot, and offers no rationale how donor coordination would affect lead donorship.

Steinwand (2013) also argues that lead donorship is driven by private interests. He presents evidence that lead donors influence the aid allocation decisions made by lower ranked donors. As the lead donor increases its aid allocations, everybody else tends to decrease their engagement. Steinwand (2013) shows that this behavior is more prevalent for aid with private good characteristics. He argues that donors who seek private benefits from giving aid can only stay the top donor for a long time because other donors choose not to contest the lead donor's top position. In fact, they grant the top donor an exclusive sphere of influence, similar to collusion in a cartel. In other words, donors seek the same benefits from aid allocations, but coordinate to reduce competition among themselves by carving up spheres of influence. A useful way to think about this relationship is a bidding war, where donors constitute multiple principals and the recipient government is the agent. In such an environment, the agent benefits from competition between principals because it can play the different principals off against each other (e.g. Grossman and Helpman 1994). In turn, coordination between the principals helps to shift rents from the agent to the principals.

Such dynamics are common in foreign aid practice. For example, a longstanding row between Namibian and German officials has been the size of the grant element of Germany's aid. Germany has been the single largest provider of bilateral aid to Namibia since the country's independence in 1990. From the beginning, Germany insisted on limiting the grant element to 30 percent, which the Namibian government did not accept because of fears of building up public debt (Katjavivi 2014). The German side eventually relented, but the issue has gained new relevance with strong increases in aid provided by the US. In an 
expert interview, a German aid official complained that American aid through the Millenium Challenge Cooperation would 'spoil the prices' because MCC provides aid entirely as grants. As a result of this, the Namibian government would be more reluctant to accept the loan element of aid and less willing to follow German guidance in program implementation. ${ }^{4}$

For our argument about the causes of lead donorship we follow Lebovic (2005) and Steinwand (2013), and assume that lead donors mainly pursue private benefits. ${ }^{5}$ The two authors use somewhat different definitions of lead donorship. In order to develop our hypotheses we need to pay attention to these differences. Lebovic (2005) considers large one-time top aid contributions as instances of lead donorship. In contrast, Steinwand (2013) requires that a lead donor remains in the top spot over a time period of several years and provides substantively more aid than other donors. ${ }^{6}$ We are interested in lead donorship that results from coordinated donor actions. This makes the long time horizon employed by Steinwand (2013) more suitable for our purposes. Coordination takes time to develop. Even if several donors are engaged in a competitive bidding war, a single donor is bound to come out on top of the heap each year, but the top spot might change hands in the next year. In contrast, coordinated behavior will result in long-lasting and persistent lead donorship. In our theoretical and empirical analysis, we therefore closely follow the conceptualization of lead donorship developed by Steinwand. What our analysis adds to Steinwand's scholarship is an explanation of the circumstances under which donors collectively step back to allow an individual top donor country to become a true lead donor with an unchallenged sphere of influence.

\footnotetext{
${ }^{4}$ Interview with official of the Federal Ministry for Economic Cooperation and Development (BMZ), Bonn, October 8, 2013.

${ }^{5}$ In making this assumption, we do not rule out that in some instances lead donorship is associated with public goods aid. Instead we concentrate here on the private goods case that is empirically supported by the two studies by Lebovic (2005) and Steinwand (2013). The factors that give rise to lead donorship in a public goods scenario are sufficiently different from the private goods scenario to justify treating the two scenarios separately.

${ }^{6}$ We discuss the precise criteria in the empirical section.
} 
The existing literature on donor coordination informs our expectations about the conditions under which lead donorship arises. Winters (2012) presents a case study of Indonesia. He identifies competition within the bureaucratic and political structures of the Indonesian government as road blocks to a more unified approach to dealing with foreign aid donors since the competing factions use their contacts to different donors as political resource. The implication of this insight is that improved donor coordination would reduce donor contacts. Government actors therefore should be opposed to concentrated aid delivery and lead donorship. At the same time, their lack of unity would also make it difficult for the Indonesian government to resist high-level donor efforts at coordination.

Turning to the donor side, Winters argues that donor self-interest in taking credit for specific aid projects and the need to develop reliable ties to specific individuals in the Indonesian bureaucracy also form obstacles to coordination.

Öhler (2013) analyzes Cambodia as aid recipient. He examines the patterns of aid provisions across delivery channels for bilateral as well as non-governmental donors, and finds no evidence of donor coordination. Though Öhler does not test for recipient country specific mechanisms or donor motivations, he concludes that donor self-interests are in the way of more effective coordination.

Lawson (2013) lists a variety of challenges to donor coordination in the context of US foreign aid practice. They include bureaucratic incentives, a lack of in-house coordination between domestic aid agencies, the costs of implementing coordination between different donors, as well as conflicting strategic interests of donors.

Summarizing the insights from this literature, the diverse interests and pressures that affect donor coordination can be divided into supply and demand factors. Demand refers to the preferences of stake holders such as recipient bureaucracies and donor governments for better coordination. Supply refers to the ability of donors to actually deliver on coordinating their actions. Successful coordination requires that stake holders want coordination, and 
donors are able to deliver. However, if recipient governments oppose donor coordination, their ability to prevent coordination on a high political level should be limited. We will draw on the distinction between demand and supply factors below when we develop our hypotheses.

There is a second body of work on donor coordination that focuses on aid allocation patterns, but does not investigate causal processes in detail. A unifying feature of this literature is that it equates fragmentation of aid delivery as indicative of a lack of donor coordination. A widely used measure of fragmentation is the Herfindahl-Hirshman index (HHI). The HHI sums up the squares of aid shares across all donors. This produces a measure of donor concentration, which then sometimes is subtracted from 1 (for a 0 to 1 scale of fragmentation). There exist many variations of this approach, each changing the basic definition slightly to emphasize certain aspects, e.g. donor dominance across sectors (Frot and Santiso 2010), or the influence of smaller donors (Nunnenkamp and Öhler 2011). In our empirical analysis, we use the measure of lead donorship developed by Steinwand (2013), which we will discuss in more detail below. The HHI and the lead donorship variable are related, because the latter only counts cases as lead donorship if aid delivery is sufficiently concentrated. ${ }^{7}$

Another approach to measure coordination is to analyze whether aid provisions by one donor are influenced by the allocation decisions of other donors. The idea is that donor coordination affects aid allocation behavior, and that joint allocation decisions can be recovered from the data. Mascarenhas and Sandler (2006) estimate different types of aid allocation functions and find no evidence of donor coordination. Steinwand (2011) identifies factors that influence free-riding in the provision of foreign aid. (Öhler 2013) tests whether the presence of donor engagement in a specific aid sector in the case of Cambodia is predicated

\footnotetext{
${ }^{7}$ This rules out situations in which aid provisions by the second and lower ranked donors almost match the allocation by the lead donor.
} 
by the engagement of other donors. He too finds no evidence of coordination. Similar work was done by Frot and Santiso (2011). The authors highlight the dynamic properties of joint donor actions known as 'herding'. They turn to a measure from financial market theory and produce some evidence of herding behavior. Finally, Fuchs et al. (2014) use the presence of two donors in one recipient country and their joint relative aid share as indicators for a lack of coordination. They find that similar export structures predict competition and a lack of coordination. These works share an emphasis on the mutual dependence of donor aid allocation decision, but we would like to learn more about the circumstances under which coordination succeeds or fails.

\subsection{Determinants of Donor Coordination}

In the following, we return to factors that affect supply and demand for donor coordination in order to develop testable hypotheses about the determinants of lead donorship. As we discussed above, we follow Lebovic (2005) and Steinwand (2013) and treat aid allocation decisions that give rise to lead donorship as primarily concerned with 'selfish' motives. That is, lead donors receive private benefits from being the top donor, as opposed to furthering developmental goals with public good properties.

Given this private goods scenario, the major stake holders in the aid process have markedly different preferences towards donor coordination. Government bureaucracies in a program country stand to lose leverage when dealing with only a single major development partner. As Winters (2012) has illustrated in the case of Indonesia, developing relationships with donor country counterparts presents a valuable source of influence for bureaucrats within their own government. As major aid flows become concentrated in the hands of only a single lead donor, these varied sources of influence for intra-agency competition threaten to dry up. As a result we expect that recipient country bureaucracies put up resistance against donor efforts to improve coordination. 
Recipient governments may also oppose donor coordination at a higher political level. The exclusive nature of lead donorship raises the specter of political dependence as well as a reduction in overall aid flows. There is considerable anecdotal evidence for this effect. Consider Namibia and Germany, after Namibia's independence from South Africa in 1990. In this year, the German parliament declared its historic responsibility for the former German colony with overwhelming support of all parties. The German government initiated an ambitious aid program, with the goal of making Namibia a 'model case' for its aid policy (Hofmeier 1991), while its foreign ministry tried to establish a leading presence in Windhoek. ${ }^{8}$ The new SWAPO-led Namibian government did not share this excitement, but rather acerbically declared that its struggle against South African colonialism did not have the goal to submit Namibia under "neo-colonial rule of the Federal Republic [of Germany] or any other country" (Hofmeier 1990, p. 24). ${ }^{9}$

More recent evidence comes from the OECD, which has studied donor coordination as part of the aid effectiveness agenda that was initiated during the fourth High Level Forum on Aid Effectiveness in Busan 2011. In three cases studies that cover Ghana, Senegal and Timor-Leste, the authors find remarkably similar preferences of policy makers calling for greater donor diversity and increased aid flows:

"Greater choice is welcome, with the benefits of more funding options seen as outweighing the complexity of managing these new sources. Seeking additional funds from a range of sources a is a priority for governments..."

Despite very different economic and political backgrounds, the governments of these three countries all indicate that they oppose more coordinated and concentrated modes of aid provision. They would rather have more diversity and increased funding levels. ${ }^{10}$

\footnotetext{
${ }^{8}$ Interview with former Ambassador to Namibi, Harald Ganns, Bonn, October 8, 2013.

${ }^{9}$ Translation by author.

${ }^{10}$ For multilateral aid, there is evidence that developing countries engage in forum shopping for loans
} 
As the previous discussion shows, strong bureaucratic and strategic incentives severely limit the demand of recipient governments for donor coordination and aid concentration. What capacity do recipient governments have to actually voice their opposition and prevent donor coordination (i.e. how do recipient country preferences affect the supply of coordination)? Local bureaucratic actors can actively sabotage donor coordination, but their ability to do so is limited to project implementation on the ground. Project implementation requires local inputs, but donor coordination with regard to lead donorship does not happen on this level. Instead, lead donorship results from strategic allocation decisions taken at higher levels of government. Although recipient governments can refuse to build exclusive ties with a prospective lead donor, as the example of Namibia and Germany in the 1990s illustrates, they are in a weak position to prevent donors from coordinating among themselves. Once other aid providers begin to disengage, the remaining main donor country will eventually be put more firmly in charge.

In the following, we take the relative weakness of recipient countries in preventing lead donorship as given. Instead we focus on the factors that drive the demand of donor countries for lead donorship and their ability to bring about collusion.

Achieving collusion poses a cooperation problem. From standard results of game theory we know that sufficiently patient actors can overcome cooperation problems when long-term gains outweigh short-term incentives to defect. However, we also know that equilibrium predictions in games with indefinite time horizon are not unique. In fact there can be an infinite number of equilibria ranging from full cooperation to permanent mutual defection. ${ }^{11}$ The question when donors respect separate spheres of influence is thus one of equilibrium selection. We need to answer under which conditions donors are able to move from an uncoordinated (competitive) equilibrium to a coordinated (collaborative) outcome.

from international institutions whose principals are in line with their political preferences (Humphrey and Michaelowa 2013).

${ }^{11}$ This is result holds for sufficiently high discount factors and is known as the Folk Theorem. 
As a start, it is helpful to explore in more detail the implications of coordination as equilibrium selection. The notion of equilibrium implies that all donors act according to mutually held beliefs about each others' expected behavior, and have no individual incentives to deviate from these expectations. ${ }^{12}$ This is different from the common understanding of coordination, which entails communication between actors. Similarly, legal prohibitions against price-fixing in the market place usually define collusion as an explicit act of coordination that involves direct contact between those who form a cartel.

In contrast, from a theoretical perspective communication is not a necessary part of equilibrium selection. The large literature on the determinants of successful collective action shows that learning from each others' actions can be sufficient to eventually arrive at a collaborative outcome (e.g. Ostrom 2000). ${ }^{13}$ There is an abundance of anecdotes that illustrate implicit collusion in the market place. For example, in 2011 the German competition watchdog agency documented and publicly admonished the five leading suppliers of gasoline in Germany for raising prices in tandem prior to holiday and vacation periods. However, the Bundeskartellamt did not take legal action because it did not posses evidence of actual communication between the companies. ${ }^{14}$

High level officials in donor governments are very unlikely to openly articulate their views on spheres of influence or directly communicate their expectations to counterparts in other donor governments. The topic is politically too sensitive since notions of influence and dependency are not acceptable to partner country governments and run afoul of official development policy as enshrined in a string of official agreements since the 1990s, such as the Millennium Declaration and the Paris Declaration. Instead, politicians often turn to

\footnotetext{
${ }^{12}$ In technical terms, choices and behavior are strategies and mutual expectations about strategies are part of the common knowledge assumption.

${ }^{13}$ Though communication clearly helps, see Hamman et al. 2011.

${ }^{14}$ Süddeutsche Zeitung, 22 May 2011, "Ölkonzerne diktieren den Preis". Accessed on 9/17/14 at http://www.sueddeutsche.de/wirtschaft/bundeskartellamt-teures-benzin-oelkonzerne-diktieren-den-preis1.1100300 .
} 
a language of historic experience and expertise. For example, when asked about France's role in sub-Saharan Africa relative to other European Union countries, the head of the subSahara directorate in France's foreign ministry replied that "France has ideas", which gives her natural policy leadership in the geographic area, while the rest of Europe would follow French initiatives (and help to underwrite them with greater financial clout). ${ }^{15}$

In settings where actors cannot or won't openly communicate, observation and learning from past experience replaces communication. We therefore expect that factors that facilitate coordination unfold their effects not instantaneously. That is, once the opportunity costs of uncoordinated competition surpass the costs of collusion, collusion does not arise immediately but only after a phase of observation and learning.

Figure 1: Learning to collude

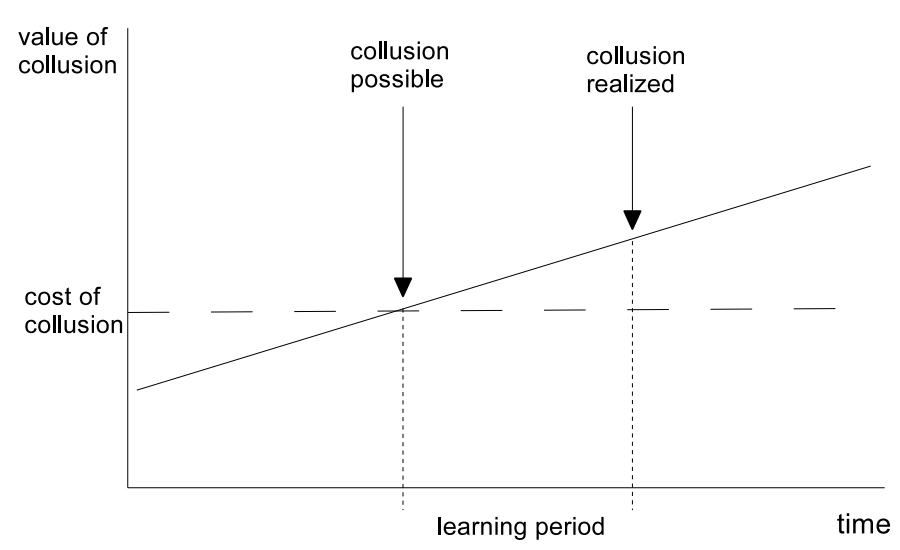

Figure 1 illustrates this mechanism. It shows a situation in which the value of collusion increases over time while the costs of collusion are constant. An example of increasing gains from collusion is the discovery of oil in a recipient country and the subsequent increase in oil exports. Costs of collusion are tied to the risks of coordination failure, for example when another donor defects, and to forgone rents to donor aid bureaucracies. ${ }^{16}$ Collusion becomes

\footnotetext{
${ }^{15}$ Interview with Yves Boudot, June 11, 2014. There exists also variation in the degree to which donor governments prefer to work with recipient governments, as opposed to bypassing them (Dietrich 2013).

${ }^{16}$ Collusion helps to increase the influence of individual donors, but aid agencies benefit from any form of
} 
feasible in principle once its gains outstrip its costs (left arrow). However, it takes a learning period for donors to adjust their expectations, therefore collusion is only realized at a later point in time (right arrow).

There is nothing in the game-theoretic study of cooperation that would tell us how long the learning period should be. Attempts at collusion can proceed in fits and starts. For example, South Africa experienced an aid boom after the end of Apartheid in the early 1990s, comparable to the above mentioned development in Mozambique. According to Genta Holmes, who served as Deputy Chief of Mission at the US Embassy in South Africa 19891990 and as first US Ambassador to the newly independent Namibiba, South Africa formed the center of attention for American and European aid activities in the region, because it promised rich economic opportunities and could serve as entry gate for the entire region. ${ }^{17}$ This onrush lead to heavily fragmented aid delivery with an average aid concentration index of $H H I=0.125$ for 1993-2003 and record lows of 0.096 in 1998 and 0.093 in 2002 (compared to a sample average of 0.31 for these years). Given this environment, individual donors could have gained much greater influence had aid delivery been more concentrated. Lead donorship looked like a desirable price, but should remain unattainable.

Although the US consistently contributed the top share of ODA during this period, its share never reached levels that could be considered evidence of exclusive lead donorship. ${ }^{18}$ This changed in 2008 and 2009, when American aid finally begun to outstrip other contributions at a scale sufficient for lead donor status. ${ }^{19}$ This delay shows that although the potential of South Africa as investment destination and export market had been evident for more than a decade, it took a substantive amount of time for American dominance to emerge.

aid activity, including competitive aid provision in the absence of collusion.

${ }^{17}$ Phone interview with Genta Holmes on May 21, 2014.

${ }^{18}$ The average share was 24.9 percent of all aid allocations.

${ }^{19}$ We will discuss the exact measure used to determine lead donorship below. 
Ultimately, the question how long it takes for donors to coordinate on lead donorship is an empirical one. A reasonable lower limit for evidence of learning is around four to five years. This is the average length of a full aid programming cycle. Donors won't be able to react to new developments considerably faster, because existing programs lock in allocation patterns for this long. Our first hypothesis summarizes our theoretical expectations about opportunities for collusion and learning.

Hypothesis 1 Collusion is feasible once the gains from collusion outstrip its costs. However, collusion does not emerge spontaneously, but only after a learning period.

So far we have discussed implications that arise from the strategic underpinnings of lead donorship, i.e. equilibrium selection and learning. However, not all prizes are equally worth fighting for. Coordination only benefits donors if they are competing for influence and the opportunity costs from forgone collusion are high. We therefore need to identify conditions under which donors have the greatest incentives to extract political and economic rents.

One of the most contentious areas of foreign aid is the promotion of the economic interests of the donor country. The promotion of economic objectives was one of the driving forces at the creation of the modern foreign aid system after world war II. For example, both Japan and Germany sought to augment their export oriented economic strategies through aid programs, though reconciliation with their neighbors also was an important goal (Lancaster 2007). Japan also specifically directed its aid to secure access to oil after the energy crises of the 1970s (Lancaster 2007, p. 116 f.). French foreign aid was openly geared toward maintaining political influence in its former colonies, but as a result French industries also often benefited through non-competitive contracts and aid-backed financing (Lancaster 2007, p. 154). These early decades also saw the extensive tying of aid to procurement of goods and services in the donor country (Jepma 1991). Aid tying directly benefits domestic constituencies of donors. 
How relevant are these practices for the contemporary aid regime? Western donors organized in the OECD's Development Assistance Committee have made sustainable development the stated goal of their aid policies, through vehicles such as the Millennium Goals and the Paris Declaration. There is not doubt that there is greater awareness of recipient country needs and a greater perception of the potential for negative backlash in global public opinion if rich western countries try to openly assert their interests. Ultimately, to what extent contemporary aid practice is still influenced by donor self-interest is an empirical question. For example, the evidence suggests that trade competition still is a driver of aid allocations (Younas 2008). Also, despite efforts to bring 'non-traditional' donors, i.e. rising economies such as the BRIC countries, into the fold of the international aid regime, countries such as China openly use aid to secure access to raw materials (Bräutigam 2011).

We argue that potential rewards from coordination drive lead donorship. As a partner country increases in economic importance for a number of donors, the economic benefits from providing aid increase as well. This in turn results in competition. Some evidence for this comes from Fuchs et al. (2014), who show that donor countries that export similar goods to a developing country also are more likely to provide aid to this country. ${ }^{20}$ We believe that such competition is a necessary pre-condition for profitable collusion among donors and the rise of lead donorship. This leads to our second hypothesis.

Hypothesis 2: As the economic relationship between recipient and donor countries increases in salience, lead donorship onset becomes more likely.

However, it is important to note that competition is only a necessary condition for collusion and by itself not sufficient. Donors may be able to realize gains from coordination, but

\footnotetext{
${ }^{20}$ The authors argue that this form of competition is indicative of a lack of coordination. This logic is complementary to our notion that lead donorship results from collusion between donors aimed to reduce competition between themselves.
} 
this depends on their ability to learn from each others' behavior and their ability to focus on the long term. The role of economic salience therefore is conditioned on the role of learning as spelled out in hypothesis 1 , and economic salience will no have instantaneous effects on the onset of lead donorship.

What other factors drive the salience of the donor-recipient country relationship? Historically, developing countries have been supported by their former colonial power upon achieving independence. As the case of francophone Africa illustrates, this initial support frequently translates into later episodes of lead donorship. In our sample, of the 32 countries that gained independence between 1975 and 2006, 15 had a lead donor from the start.

Colonial relations are a powerful coordination mechanism because they provide a focal point for donor expectations about spheres of influence (Schelling 1960). The colonial power even can try to influence the timing of independence to maximize its chances of maintaining influence. However, it seems reasonable that the relevance of colonial ties deteriorates over time as other donor countries begin to develop and articulate their own interests with regard to the newly independent state. Thus, the passage of time might lead to increased competition among donors for the top spot. In contrast to our argument about learning articulated in hypothesis 1, these pressures will not be balanced by learning effects (since expectations are already coordinated), but should make it more difficult to maintain coordination as time goes on. Another way to think about this is that the interests of the former colonial power and other donors might not be stable in the long run, and a once stable sphere of influence can become more contested later. We summarize these expectations about the influence of the colonial past and its decline over time in the following hypothesis.

Hypothesis 3 Former colonies are more likely to experience lead donor onset. The longer a country is independent, these effects decrease. 
Complementary to the role of colonial history, the onset of independence also provides interesting testing grounds how coordination evolves in countries that neither experienced lead donorship at independence nor were colonies of great powers. Without initial lead donorship or a strong colonial power, there is no focal point for coordinating on a single lead donor. In line with hypothesis 1 , we therefore would expect that it takes some time for coordination to develop.

Hypothesis 4: For countries without colonial history and lead donor at independence, lead donorship onset is less likely. Onset becomes more likely the longer the country is independent.

\section{Empirical Analysis}

The key dependent variable is the onset of lead donorship. We rely on the operationalization developed by Steinwand (2013). A country counts as lead donor if it enjoys an exclusive position, as measured by three different indicators. ${ }^{21}$ It also must be the largest aid contributor in 5 out of 9 years. ${ }^{22}$ The patterns of complementarities and substitution behavior that Steinwand presents as evidence of coordination behavior are robust against a number of variations including different time windows for the determination of lead donorship. ${ }^{23}$. We reproduce the analysis presented below with these specifications, and our findings remain unchanged. ${ }^{24}$

\footnotetext{
${ }^{21}$ Overall fragmentation of aid delivery must be low, the lead donor's aid share must be sufficiently large relative all other donors, and there must be a significant contribution gap between the first and secondlargest aid contributions. To count as lead donor, a country must lie above the sample median for all three variables.

${ }^{22}$ In addition, the country also most not relinquish this position for more than 2 years in a row. This additional condition helps to better identify the end and beginning of lead donorship spells.

${ }^{23}$ Requiring top donor status in 4 out of 7 and 3 out of 5 consecutive years

${ }^{24}$ We report results in table 6 in the appendix.
} 
Turning to independent variables, we use two sets of variables to measure economic selfinterest in aid provision. The first set directly taps into bilateral economic interests. We look at the importance of specific countries as destination for exports originating from donor countries. In line with classic explanations of donor motives, foreign aid can help secure market share in this export market. To measure the importance of exports, we aggregate total yearly trade flows from all donor countries to a given partner country. A second area in which aid traditionally has served to further economic donor self-interest is access to oil. We calculate aggregate oil exports from a given producer to all donor countries. ${ }^{25}$ Our expectation is that as the potential gains from collusion increase alongside economic activity, it becomes increasingly likely that lead donorship emerges.

Flows of goods and services are subject to short-term fluctuations, but we have argued that coordination takes time to unfold. Brief ups and downs in oil and trade flows therefore should not affect the propensity of lead donorship onset. To capture the sustained nature of economic relations that will induce lead donorship we take a series of moving averages of the oil and trade variables. Looking backward up to 7 years, these moving averages smoothen short-term fluctuations and represent long-term trends in oil production and trade relationships. We expect that any effect of our economic salience variables will only unfold in the long run, not the short run.

We also include a set of economic controls. To capture a country's economic potential we include population size, GDP per capita, and GDP growth. ${ }^{26}$ In contrast to trade in oil and other goods, the connection to self-interested donor behavior is less straightforward. GDP per capita is an indicator of recipient need, but also of economic potential. Arguably, the competitive element of aid provision is smaller as program countries have greater needs and less to offer economically, dampening the propensity for lead donorship. GDP growth

\footnotetext{
${ }^{25}$ Both oil and trade data are from Comtrade (United Nations 2012).

${ }^{26}$ Taken from the World Development Indicators (World Bank Group 2012).
} 
captures economic potential, and as such is an indicator of future economic opportunity. This could serve as driver of competition between donors, and thus may make donor coordination desirable. At the same time, under conditions of a dynamically growing economy there is more uncertainty and coordination therefore might be harder to attain. As last measure of economic potential we use population size. Larger countries naturally provide greater opportunities for exports and investment, making them more appealing targets for the strategic use of foreign aid.

Next, we turn to the specific path that a country took to independence. We code a dummy variable for countries that were the colony of a major power, including the UK, France, the US, Spain and Japan. We interact this dummy with the years since independence to capture diminishing effects of colonial legacy as spelled out in hypothesis 3. We also code a dummy variable for countries that neither had a lead donor at independence, nor had one of the major powers as colonial ruler. We interact this dummy variable also with the years since independence, to test whether learning effects exist. It should be noted that both dummy variables are highly correlated. We therefore estimate separate specifications for each.

Competition is not the only mechanism that can lead to interconnected aid allocation decisions. External stimuli also have the potential to induce donors to behave in similar ways. For example, the donor community may react to catastrophic events in recipient countries that have a huge impact in humanitarian terms. Similar actions brought about by external events are conceptually different from coordination, but are observationally equivalent. ${ }^{27}$ Fortunately, in the case of lead donorship, humanitarian needs will make it harder for donors to keep up any collusive arrangements. Thus, lead donorship will become less prevalent as humanitarian aid begins to pour in from around the world. We include two variables. The first is a count of natural and man-made disasters, and the second an indicator for armed

\footnotetext{
${ }^{27}$ See for example the discussion of external shocks in Hennessy and Steinwand (2014) and of 'umbrella causation' in Franzese and Hays (2007).
} 
civil conflict. ${ }^{28}$

Figure 2: Onset, end of lead donorship, donor concentration over time

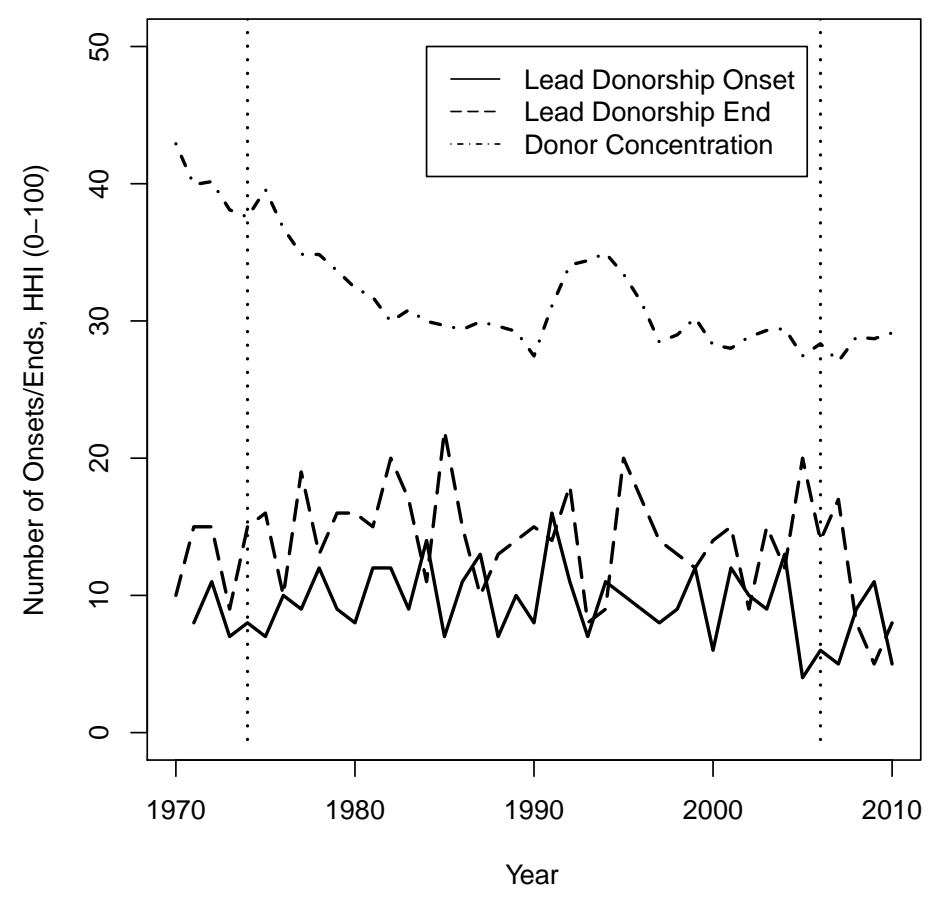

Before going to the multivariate analysis, we take a look at descriptive statistics. Figure 2 plots the annual frequencies of onset and end of lead donorship spells over the years in the analysis, as well as the average HHI. The vertical doted lines mark the range for which the lead donor measure is fully reliable. Before 1974 and after 2006 we will undercount the true number of lead donor episodes because of the necessity to take lags and leads in determining lead donorship. We can observe a number of broad trends. Over the years, the donor system grows increasingly fragmented, as HHI values decline. This is in line with the narrative underlying the current debate about donor fragmentation. The time trends

\footnotetext{
${ }^{28}$ Disaster data is taken from the EM-DAT database (Université catholique de Louvain 2013) and civil war data from the Armed Conflict Dataset (Gleditsch et al. 2002). For time-delayed effects of these variables we calculate multi-year counts instead of moving averages.
} 
for lead donorship onset and end are less pronounced. However, the number of new lead donorship spells seems to decline somewhat over time. More importantly, the number of spells that come to an end consistently lies above the number of new lead donor episodes. Accordingly, the total number of partner countries that have a lead donor in any given year falls throughout the period under observation. In fact, whereas in the mid-1970s almost 40 percent of all recipient countries had a lead donor, the last reliable numbers show that in 2006 it was only 18 percent. The 1970s mark the tail-end of a process of decolonization, particularly in Africa, that had taken its beginning in the 1950s. The graph reveals that lead donorship onset is not becoming more rare, but that the number of countries exiting lead donorship is consistently higher than those that start a new lead donor spell.

In table 1 we summarize the independent variables broken down by lead donorship status as well as for the entire sample. A quick glance reveals that countries that have a lead donor are better off than those without lead donor. They tend to be wealthier, they export more oil to donor countries and import more goods from them. They also experience fewer man-made and natural disasters. On the other hand, countries with lead donor tend to be smaller in terms of population, their economies grow more slowly, and a higher share of them experiences armed civil conflict. Lead donor countries also are more likely to be a former colony of a great power (UK, France, Spain, US and Japan). Since many of these characteristics vary together, we need to turn to multi-variate regression analysis to be able to tease out effects of individual variables.

To model lead donorship onset we use a standard event-history setup with a cloglog-link. ${ }^{29}$ The dependent variable takes a value of 1 in the presence of a lead donor and 0 otherwise. We include natural splines into the analysis to model the baseline hazard of obtaining/losing a lead donor, and drop observations of ongoing lead donorship from the analysis. Thus we

\footnotetext{
${ }^{29}$ The cloglog specification is the discrete-time equivalent of the Cox-proportional hazard model in continuous time (Alt et al. 2001). It is therefore the appropriate choice for an event history setup and our preferred model. However, the substantive differences between the cloglog and logit estimates are very small.
} 
Table 1: Descriptive statistics independent variables

\begin{tabular}{lllllll} 
& \multicolumn{2}{l}{ Full sample } & \multicolumn{2}{c}{ No lead donor } & \multicolumn{2}{c}{ With lead donor } \\
& median & mean & median & mean & median & mean \\
\hline GDP per capita, US\$ & 1,190 & 2,840 & 1,100 & 2,820 & 1,410 & 2,920 \\
GDP growth, percent & 4.20 & 3.93 & 4.26 & 3.97 & 4.08 & 3.81 \\
No lead donor at independence & & & & & & \\
or no former colony, percent & & 41.4 & & 45.2 & & 29.4 \\
Years since independence & 28.0 & 63.4 & 28.0 & 63.7 & 29.0 & 62.6 \\
Former colony of major power, percent & & 64.3 & & 60.7 & & 75.7 \\
Population, million & 4.51 & 27.1 & 5.07 & 28.8 & 3.21 & 21.7 \\
Oil exports per capita, US\$ & 0.00 & 130 & 0.00 & 120 & 0.00 & 161 \\
All imports per capita, US\$ & 100 & 601 & 78.3 & 604 & 177 & 595 \\
Number of disasters & 0.00 & 2.05 & 0.00 & 2.13 & 0.00 & 1.82 \\
Conflict, percent & & 15.1 & & 14.4 & & 17.4
\end{tabular}

seek to explain the beginning of a lead donorship term. As mentioned above, our results are robust against different measures of lead donorship. In addition, we rerun the analysis with jackknifed standard errors to check for the influence of outliers and violations of the asymptotic normality assumption, resulting in substantively unchanged results. ${ }^{30}$

Table 2 reports results for our preferred specification. All economic variables are averaged over 4 years, from $t=-3$ to the present, $t=0$. For disasters and conflict years, we include the aggregate total over four years. In addition, we add a one-year time lag to all independent variables to ensure that events in the independent variables precede outcomes. We begin with the economic variables. In model 3, we enter the variables without controls or history dependent variables, and model 4 features the complete specification. Results are essentially identical. The bilateral economic activities that form a direct source for rent extraction have the expected effect. Oil exports to donor countries and imports from donor countries are associated with an increased probability of lead donorship. The relationships

\footnotetext{
${ }^{30}$ Results in table 7 in the appendix. Confidence in coefficients decreases moderately across the board, as is common with jackknifed results (model 1). For oil, the loss of significance is stronger. However, results are restored after a log transformation removes the heavy skew of the variable (model 2).
} 


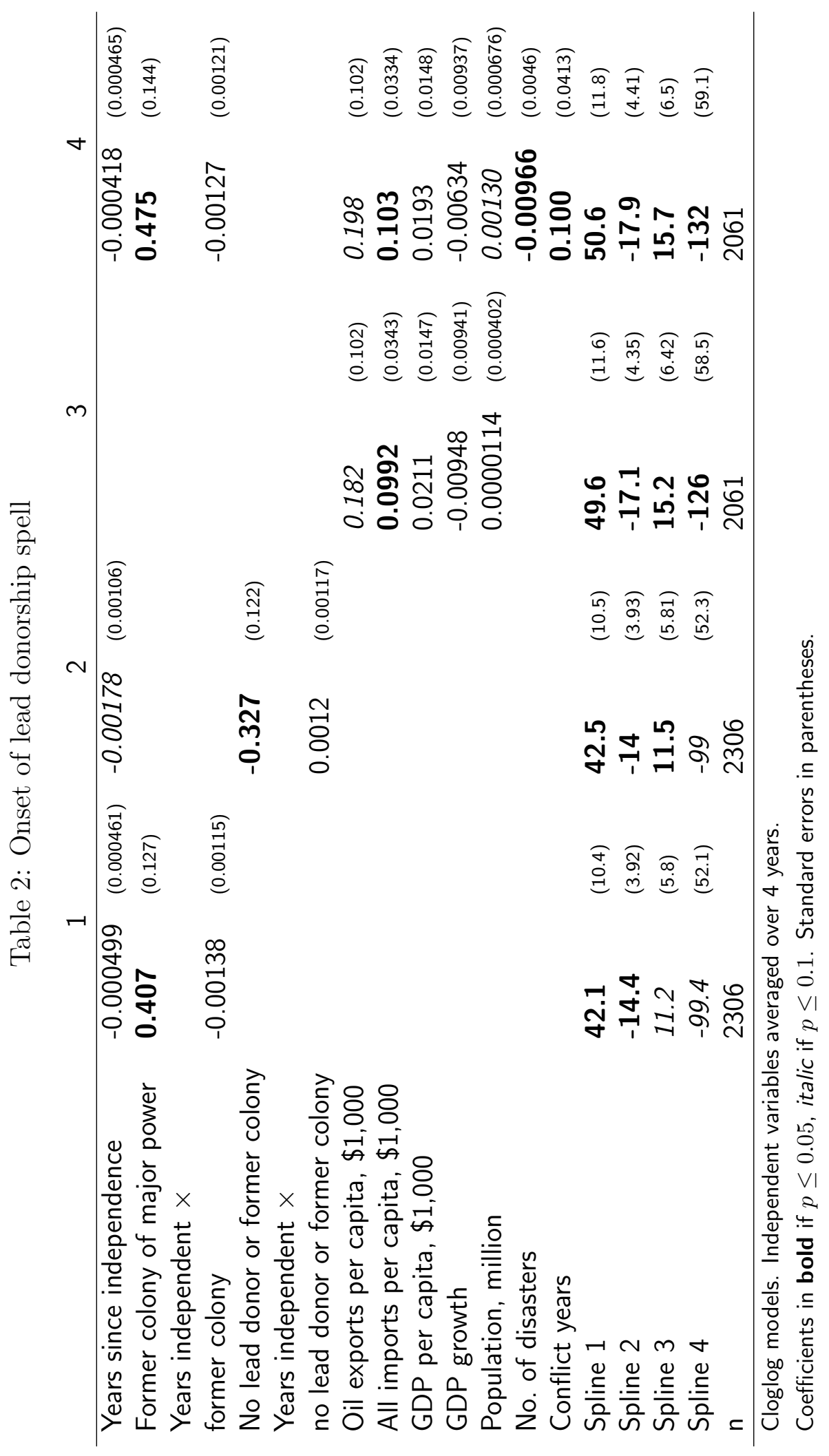


are statistically significant (oil $p=0.0534$, trade $p=0.0207$ ), and both variables have large substantive effects. Using the average predicted probability of lead donorship onset of 18.2 percent as baseline (for the actual values of $\boldsymbol{X}$ in the sample), an increase of oil exports worth $\$ 1,000$ per capita adds 3.4 percentage points to the probability of lead donorship. For imports from donor countries, a $\$ 1,000$ per capita increase contributes 1.7 percentage points. Figure 3 plots these marginal effects. The effects are especially important for major oil exporting countries. For the top $1 \%$ of cases in the sample, oil exports lie above $\$ 3,000$ per capita (using a 4-year moving average), whereas the median country has no oil exports. The importance of trade is more widely shared. For more than $13 \%$ of all observations in the sample, annual imports from donors lie above $\$ 1,000$ (again using a 4-year moving average).

Figure 3: Marginal effects, baseline probability $18.2 \%$

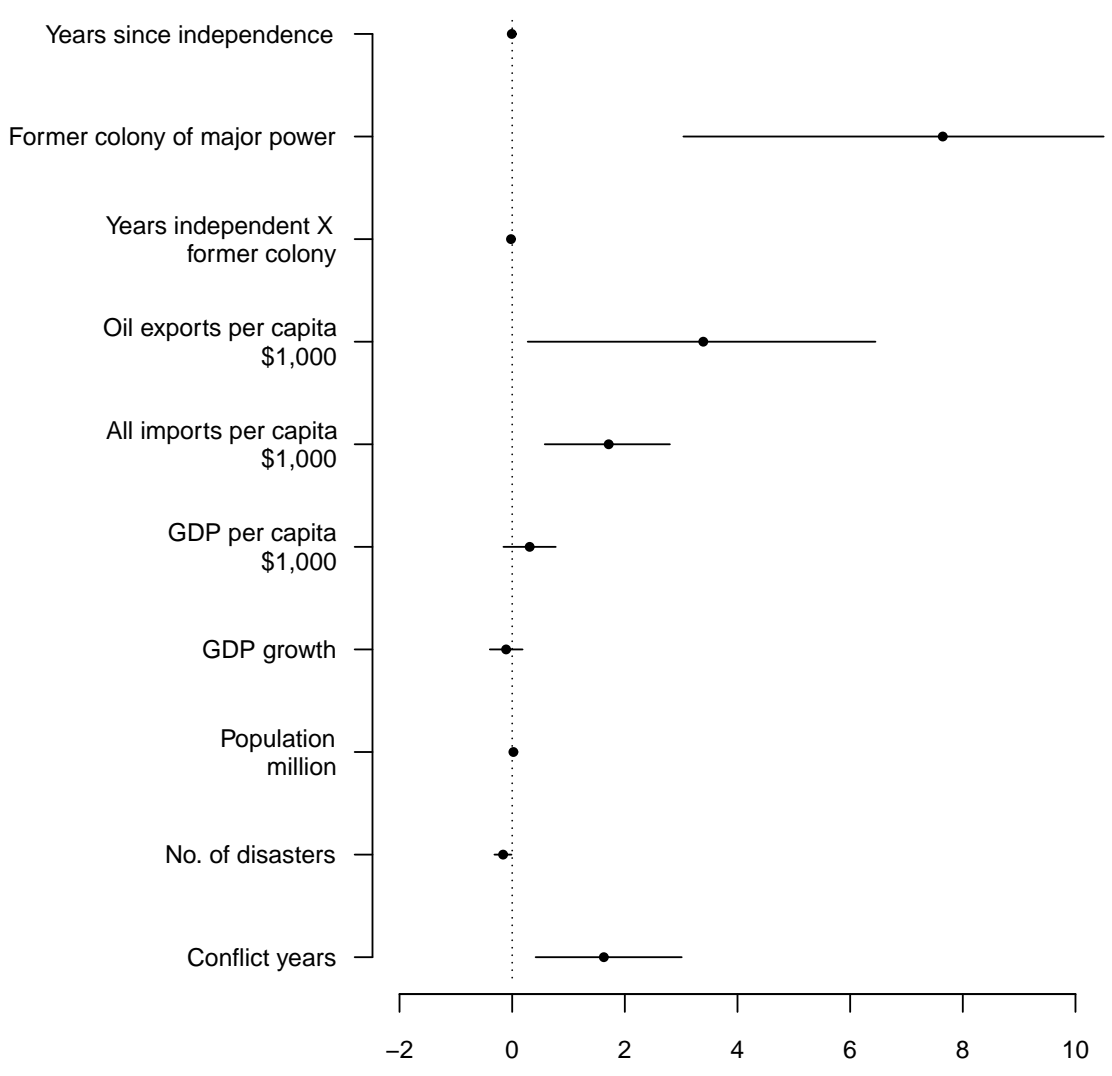


The variables that tap into general economic potential have no discernable effects. GDP per capita and growth are not statistically significant. As expected, population size increases the probability of lead donorship, but only in the in the full model $(p=0.053)$. Without controls and other independent variables (model 3), we don't have evidence of this relationship, lowering our overall confidence in the effect.

The results in table 2 reflect our preferred specification, with 4 year moving averages and aggregate totals of the independent variables. In line with hypothesis 1 , we expect that lead donor onset does not react to short-term fluctuations in economic conditions, since donors need to learn how to coordinate their aid responses to realize gains from collusion. To explore this learning effect, we run the analysis with varying time windows ranging from 1 to 7 years. We summarize the results for the economic variables in figure 4 . Oil exports and total imports have a positive impact on the likelihood of lead donor onset throughout. However, effect sizes increase when looking back longer. Oil exports cross the 95 percent confidence threshold when averaging over at least 4 years, imports for 2 years and more. This provides strong support for the learning hypothesis.

GDP per capita and GDP growth are broader measures of economic well-being, with less clear-cut expectations for competition and learning. ${ }^{31}$ Interestingly, lead donor onset appears sensitive to short-term variation in general economic activity but not to longer time trends. Lead donor onset reacts negatively to short-term up-ticks in growth, but not to sustained growth episodes. At the same time, higher GDP per capita levels predict onset when measured in the short run, but not when taking multi-year averages. This is a somewhat contradictory pattern, since short-term up-ticks in wealth are a function of growth. The contradiction cannot be explained by multi-collinearity (correlation $\rho=0.052$ ), and interacting the two variables produces no evidence of a significant interaction effect. As the descriptive statistics in table 1 have shown, lead donor countries tend to be wealthier

\footnotetext{
${ }^{31}$ We omit overtime trends for population, since this variable does not vary sharply over time.
} 
and slower growing than countries without lead donor. It is therefore possible these variables are picking up endogeneity (i.e. a looming lead donorship spell inducing lower growth and higher gdp per capita) when used without longer moving averages.

Figure 4:
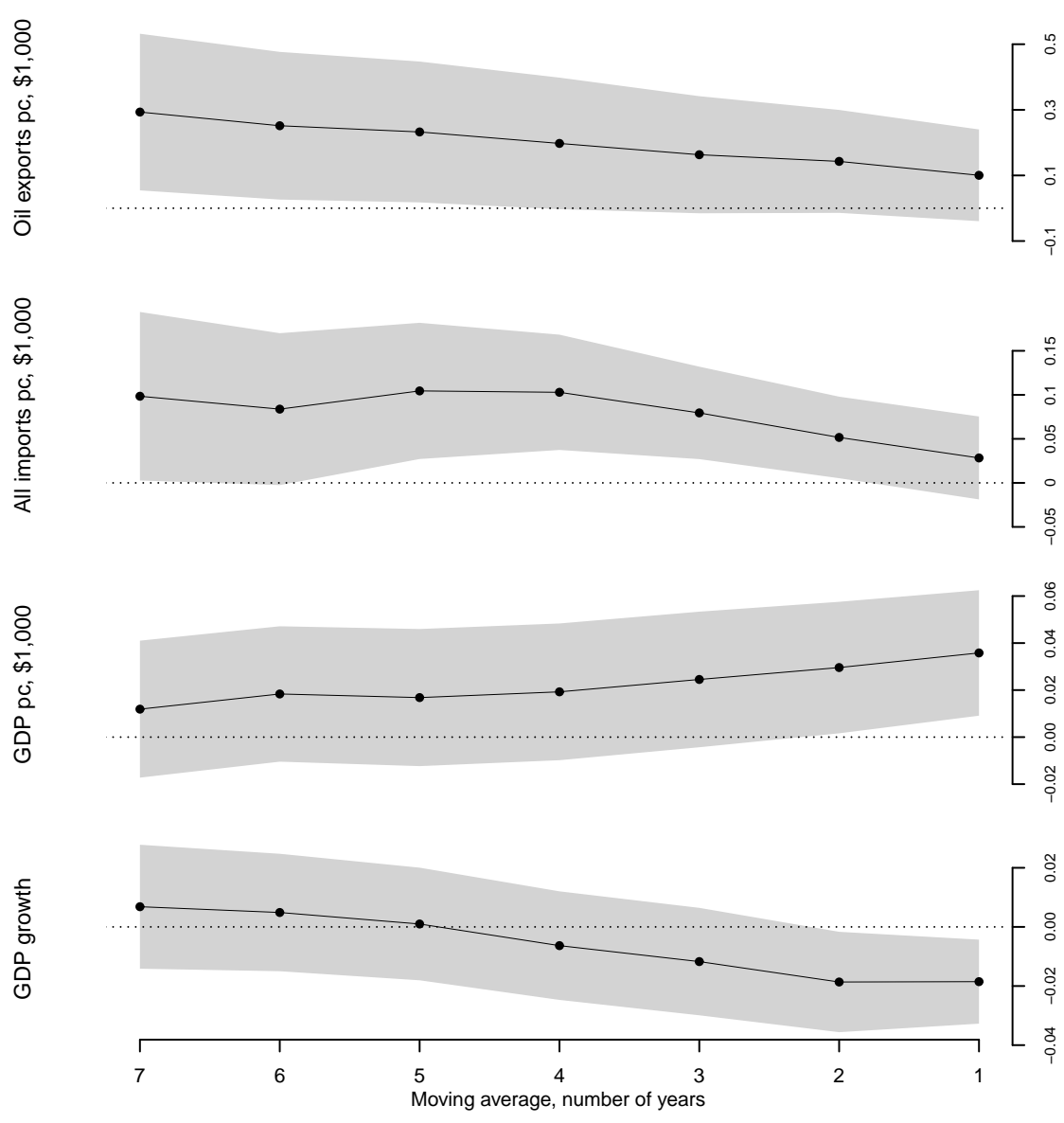

We next turn to the role of colonial history. As summarized in hypothesis 3 , former colonies should be more likely to experience lead donorship onset because history serves as focal point for donor coordination. Returning to table 2, we see that this is the case. Former colonies of major powers have a statistically significant higher probability of lead donorship onset, both by themselves (model 1) and in the full model (model 4). For the average country in the analysis, the substantive increase amounts to 7.6 percentage points over the baseline of 
18.2 percent, a huge effect. The influence of the colonial experience attenuates over time, but the coefficient for the interaction between time since independence and the colonial history dummy is too small to reliably distinguish it from zero.

Figure 5: Share of former colonial powers as lead donor

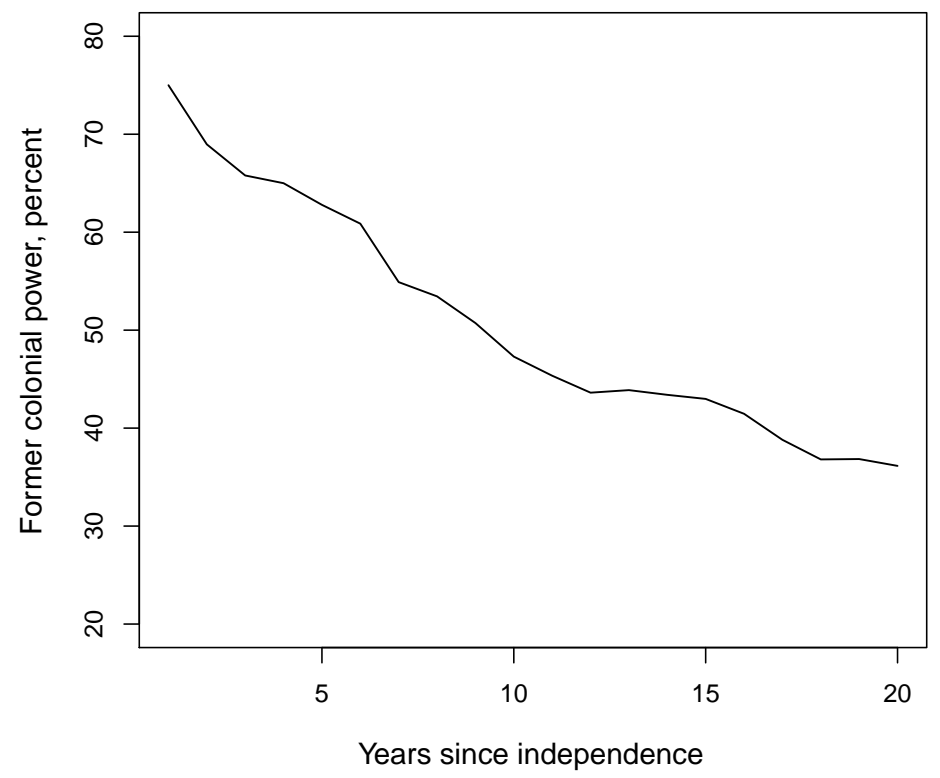

Colonial history is a clear driver of lead donor activity, but the analysis cannot determine the identity of the lead donor. To address this, we plot in figure 5 the share of instances in which the lead donor at the onset of a lead donorship spell is the former colonial power. In the year after independence, fully 75 percent of new lead donors are the former colonizer. As time passes, this proportion continuously decreases. Over 20 years, the average share of former colonial powers among new lead donors sinks to around 36 percent. These patterns generate two interesting insights. First, the passage of time in fact matters as former colonial powers are much more likely to take up the role as lead donor shortly after independence than after a number of years. At the same time, our statistical analysis shows that former colonies continue to have an increased probability of lead donorship onset for several years after independence. Second, we therefore have evidence that the historic effects of colonial- 
ism persist even as the influence of the former colonial power decreases. For the revealed empirical pattern to hold, it must be true that other donors take over as new lead donors once the former colonial power retreats. This suggests that something about the colonial experience itself makes developing countries more persistent targets for donor collusion and lead donorship.

Returning to table 2 , we find further confirmation for the persistent effects of colonialism when only looking at countries that neither had one of the major powers as colonizer nor started out with lead donor after independence (model 2). ${ }^{32}$ On average, these countries have a 5.4 percentage points lower probability of lead donorship onset. In line with hypothesis 4 we expect a positive sign of the interaction between time since independence and absence of colonial history, as donors learn how to coordinate when dealing with such countries. The coefficient of the interaction term is in fact positive, but it is too small to be statistically significant.

Turning to the control variables, natural catastrophes and civil conflict have appreciable effects on lead donorship. As we expected, natural catastrophes make lead donorship less common, as humanitarian aid begins to flow in. For each occurrence of disaster, the probability of lead donorship onset decreases by 0.16 percentage points. To put this into perspective, the average country in the analysis experiences 2.05 disasters per year, but some reach as high as 101 (China in 2005). Surprisingly, civil conflict has the opposite effect. For each year of internal fighting the likelihood of lead donorship onset increases by 1.7 percentage points. One possible reason for this could be that lead donorship itself makes conflict more likely.In our sample, conflict is pervasive, with one in six countries experiencing civil war in any given year. The relationship between donor concentration and political stability clearly deserves attention in future research .

\footnotetext{
${ }^{32}$ We do not include this dummy variable in the full model because it is strongly co-linear with the colony dummy.
} 
We conclude the empirical discussion with a look at model fit. Table 3 reports classification results for our preferred model for different probability thresholds. The generic standard for classification is the 50 percent threshold, since a prediction of 50 percent of an event occurring usually is equal to a random guess. Using this threshold, our preferred model performs not great. It correctly identifies only 17 of 377 lead donorship onsets, (sensitivity 4.5 percent). On the other hand, it correctly predicts non-onset in 1,670 of 1,684 cases (specificity 99.2 percent). The high specificity and great number of non-occurrences in the data translate into an overall classification rate of 81.6 percent.

Table 3: Classification performance, lead donorship onset

\begin{tabular}{|c|c|c|c|c|c|c|}
\hline & \multicolumn{3}{|c|}{$50 \%$ threshold } & \multicolumn{3}{|c|}{$19.8 \%$ threshold } \\
\hline & \multicolumn{2}{|c|}{ Observed } & \multirow[t]{2}{*}{ Totals } & \multicolumn{2}{|c|}{ Observed } & \multirow[t]{2}{*}{ Totals } \\
\hline Predicted & & & & & & \\
\hline & 0 & 1 & & 0 & 1 & \\
\hline 0 & 1,670 & 360 & 2,030 & 1,155 & 134 & 1,289 \\
\hline 1 & 14 & 17 & 31 & 529 & 243 & 772 \\
\hline Totals & 1,684 & 377 & 2,061 & 1,684 & 377 & 2,061 \\
\hline
\end{tabular}

Since we are interested in predicting lead donorship onset, the low sensitivity of the model is not offset for by the high classification rate. However, the 50 percent threshold is arbitrary in the sense that it represents a 'better than random' guess. Since lead donorship onset itself is a low-probability event, the standard of what constitutes a random guess should be lowered accordingly. Picking any country-year in our sample at random, the chance of drawing a lead donorship onset is only 19.8 percent. Once we add the information entailed in the independent variables of our statistical model, predicted probabilities greater than 19.8 percent can be thought of as providing a better than random guess of lead donorship onset. When gauged by this standard, our preferred model performs quite well. It correctly predicts 243 out of 377 onset episodes (sensitivity 64.5 percent) and 1,155 of 1,684 non-onsets (specificity 68.6 percent). Although this results in an overall lower classification rate of 68.8 
percent, the drastically improved sensitivity more than outweighs this decrease.

Since classification thresholds are ultimately arbitrary, Greenhill et al. (2011) propose the use of separation plots to asses model fit across the entire range of predicted probabilities. Figure 6 shows the separation plot for our preferred model. The plot sorts all observations in the data in order of ascending predicted probability of lead donor onset, shading actual cases of onset black and leaving non-onset events white. The plot line represents the predicted probability of onset. The plot shows that our model does a good job separating non-onsets from onsets, with relatively few onsets located in the left-hand of the plot and many more on the right-hand side.

Figure 6: Separation Plot for Preferred Model

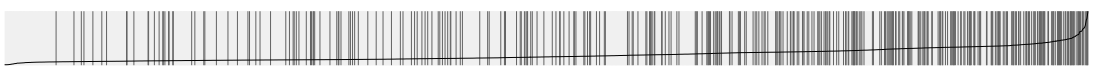

It is interesting to note that we were not able to increase model fit using econometric fixes such as regional intercepts and year-dummies. Together with the good classification performance, this underlines the soundness of our specification choices and further strengthens confidence in our findings.

\section{Conclusion}

In this study we have set out to explore under which circumstances countries that receive Official Development Aid have most of their aid provided by only one single top donor. This form of lead donorship forms a counterpole to donor fragmentation. The current debate about fragmentation centers on the role of coordination between donors. We argue that lead donorship arises as a result of implicit coordination between donors who delineate spheres 
of influence to enjoy private benefits from aid. Our empirical analysis shows that lead donorship is more prevalent where economic gains, specifically oil exports and goods flowing from donor to recipient countries, promise greater benefits from reduced competition. In addition, colonial history predispositions countries to experience lead donorship even long after the original colonial power has departed and begun to disengage.

Our findings on the determinants of lead donorship underline that donor coordination is not automatically beneficial to recipient countries. This fits in with quietly articulated concerns of partner country officials who worry that improved coordination under the auspices of the OCED will result in less political leverage over aid programming and lower overall aid volumes. On the upside, our findings demonstrate that providing discernable private benefits to donors might help to induce coordination. Since aid programming typically involves a mixture of delivery modes and projects, including those purely for development purposes, it remains unclear whether targeted private payoffs would be enough to change aid practices across the entire range of aid programming. In addition, partner countries that suffer most from fragmentation are relatively poor and have vulnerable state institutions. Donor coordination that revolves around the exploitation of economic opportunities seems highly unlikely in these settings.

Although lead donorship remains an important reality of aid practice, with around 20 percent of all partner countries being served by a lead donor, the role of economic self-interest in OECD aid provisions clearly has declined over the last quarter century. Our results show that future research on donor coordination needs to pay closer attention to the mixture of private and public good motives driving aid provision. A more fine-grained approach could usefully distinguish challenges to coordination in specific sectors and for aid that is provided through different delivery channels. 


\section{References}

Alt, James E., Gary King, and Curtis S. Signorino. 2001. "Aggregation Among Binary, Count, and Duration Models: Estimating the Same Quantities from Different Levels of Data." Political Analysis :21-44.

Bräutigam, Deborah. 2011. "Aid 'With Chinese Characteristics': Chinese Foreign Aid and Development Finance Meet the OECD-DAC Aid Regime." Journal of International Development 23:752-764.

Dietrich, Simone. 2013. "Bypass or Engage? Explaining Donor Delivery Tactics in Foreign Aid Allocation." International Studies Quarterly 57:698-712.

Djankov, Simeon, Jose G. Montalvo, and Marta Reynal-Querol. 2009. "Aid with Multiple Personalities." Journal of Comparative Economics 37:217-229.

Dreher, Axel, Peter Nunnenkamp, and Maya Schmaljohann. forthcoming 2015. "The allocation of German aid: Self-interest and government ideology." Economics 85 Politics

Easterly, William. 2007. “Are Aid Agencies Improving?" Economic Policy 22:633-678.

Ericsson, Frederik, and Suzanne Steensen. 2014. Where Do We Stand on Aid Orphans?. OECD-DAC Development Brief, OECD Development Co-operation Directorate. Accessed online on 8/24/2014 at http://www.oecd.org/dac/aidarchitecture/Aid\%20Orphans\%20Development\%20Brief.pdf.

Franzese, Robert J., and Jude C. Hays. 2007. "Spatial Econometric Models of Cross-Sectional Interdependence in Political Science Panel and Time- Series-Cross-Section Data." Political Analysis 15:140-164. 
Frot, Emmanuel, and Javier Santiso. 2010. "Crushed Aid: Fragmentation in Sectoral Aid." Working Paper 248. Paris: Development Centre, OECD.

Frot, Emmanuel, and Javier Santiso. 2011. "Herding in Aid Allocation." Kyklos 64:54-74.

Fuchs, Andreas, Peter Nunnenkamp, and Hannes Öhler. 2014. "Why donors of foreign aid do not coordinate: The role of competition for export markets and political support." The World Economy Doi:10.1111/twec.12213.

Gleditsch, N.P., P. Wallensteen, P. Eriksson, M. Sollenberg, and H. Strand. 2002. "Armed Conflict 1946-2001: A New Dataset." Journal of Peace Research 39:615-637.

Greenhill, Brian, Michael D Ward, and Audrey Sacks. 2011. "The separation plot: a new visual method for evaluating the fit of binary models." American Journal of Political Science 55:991-1002.

Grossman, Gene M., and Elhanan Helpman. 1994. "Protection for Sale." American Economic Review 84:833-850.

Hamman, John R., Roberto A. Weber, and Jonathan Woon. 2011. "An Experimental Investigation of Electoral Delegation and the Provision of Public Goods." American Journal of Political Science 55:737-751.

Hennessy, Alexandra, and Martin C. Steinwand. 2014. "The Sources of Pension Reforms in Europe: Domestic Factors, Policy Diffusion, or Common Shock?" International Interactions 40:477-505.

Hofmeier, Rolf. 1990. "Deutsch-afrikanische Beziehungen 1989." In Afrika Jahrbuch 1989: Politik, Wirtschaft und Gesellschaft in Afrika südlich der Sahara. Opladen: Leske + Budrich, 23-30. 
Hofmeier, Rolf. 1991. "Deutsch-afrikanische Beziehungen 1990." In Afrika Jahrbuch 1990: Politik, Wirtschaft und Gesellschaft in Afrika südlich der Sahara. Opladen: Leske + Budrich, 24-31.

Humphrey, Chris, and Katharina Michaelowa. 2013. "Shopping for development: multilateral lending, shareholder composition and borrower preferences." World Development 44:142155.

Jepma, Catrinus J. 1991. The Tying of Aid. Paris: OECD Development Centre.

Katjavivi, Peter H. 2014. "Namibia's bilateral relations with Germany: A crucial relationship." In Namibia's Foreign Relations: Historic Contexts, Current Dimensions, and Perspectives for the 21st Century, eds. Anton Bösl, André du Pisani, and Dennis U Zaire. Windhoek: Macmillan Education Namibia, 135-168.

Kilby, Christopher. 2013. "An empirical assessment of informal influence in the World Bank." Economic Development and Cultural Change 61:431-464.

Knack, Stephen, and Aminur Rahman. 2007. "Donor fragmentation and bureaucratic quality in aid recipients." Journal of Development Economics 83:176-197.

Lancaster, Carol. 2007. Foreign Aid: Diplomacy, Development, Domestic Politics. Chicago, IL: University of Chicago Press.

Lawson, Marian Leonardo. 2013. Foreign Aid: International Donor Coordination of Development Assistance. No. 7-5700 in CRS Report for Congress, Congressional Research Service.

Lebovic, James H. 2005. "Donor Positioning: Development Assistance from the U.S., Japan, France, Germany, and Britain." Political Research Quarterly :119-126. 
Mascarenhas, Raechelle, and Todd Sandler. 2006. "Do Donors Cooperatively Fund Foreign Aid?" Review of International Organizations 1:337-357.

McKinlay, Robert D, and Richard Little. 1977. "A foreign policy model of US bilateral aid allocation." World Politics 30:58-86.

McKinlay, Robert D, and Richard Little. 1978. "A foreign-policy model of the distribution of British bilateral aid, 1960-70.” British Journal of Political Science 8:313-331.

McKinley, Robert D, and Richard Little. 1979. "The US Aid Relationship: A test of the recipient need and donor interest models." Political Studies 27:236-250.

Morgenthau, Hans. 1962. "A Political Theory of Foreign Aid." American Political Science Review 56:301-309.

Nunnenkamp, Peter, and Hannes Öhler. 2011. "Aid Allocation Through Various Official and Private Channels: Need, Merit and Self-Interest as Motives of German Donors." World Development 39:308-323.

OECD. 2005. The Paris Declaration on Aid Effectiveness and the Accra Agenda for Action. Paris: OECD.

Öhler, Hannes. 2013. "Do Aid Donor Coordinate Within Recipient Countries?" University of Heidelberg, Department of Economics, Discussion Paper Series 539.

Olson, Jr., Mancur, and Richard Zeckhauser. 1966. "An Economic Theory of Alliances." The Review of Economics and Statistics 48:266-279.

Ostrom, Elinor. 2000. "Collective Action and the Evolution of Social Norms." The Journal of Economic Perspectives 14:137-158.

Schelling, Thomas C. 1960. The Strategy of Conflict. Cambridge,: Harvard University Press. 
Steinwand, Martin C. 2011. "Estimating Free-Riding Behavior: The StratAM Model." Political Analysis 19:488-502.

Steinwand, Martin C. 2013. "Compete or Coordinate? Aid Fragmentation and Lead Donorship." International Organization In print. Accessed online on 10/24/14 at http: //mysbfiles.stonybrook. edu/ msteinwand/papers/Steinwand2013. I0.final.pdf.

Steinwand, Martin C., and Raynee Gutting. 2012. "Donor Fragmentation, Aid Shocks, and Violent Political Conflict." Working Paper. Stony Brook University.

United Nations. 2012. United Nations Commodity Trade Statistics Database. Available from 〈http://comtrade.un.org/db/default.aspx 〉. Accessed 24 May 2012.

Université catholique de Louvain. 2013. "EM-DAT: The OFDA/CRED International Disaster Datebase." Brussels, Belgium. Accessed online on 7/10/2013 at www.emdat.be.

Winters, Matthew S. 2012. "The Obstacles to Foreign Aid Harmonization: Lessons from Decentralization Support in Indonesia." Studies in Comparative International Development $47: 1-26$.

World Bank Group. 2012. "World Development Indicators Online." Accessed online on 5/20/2012 at http://databank.worldbank.org/ddp/home.do?Step=12\&id=4\&CNO=2.

Wright, Joseph, and Matthew Winters. 2010. "The politics of effective foreign aid." Annual Review of Political Science 13:61-80.

Younas, Javed. 2008. "Motivation for Bilateral Aid Allocation: Altruism or Trade Benefits." European Journal of Political Economy 24:661-674. 


\section{Appendix}




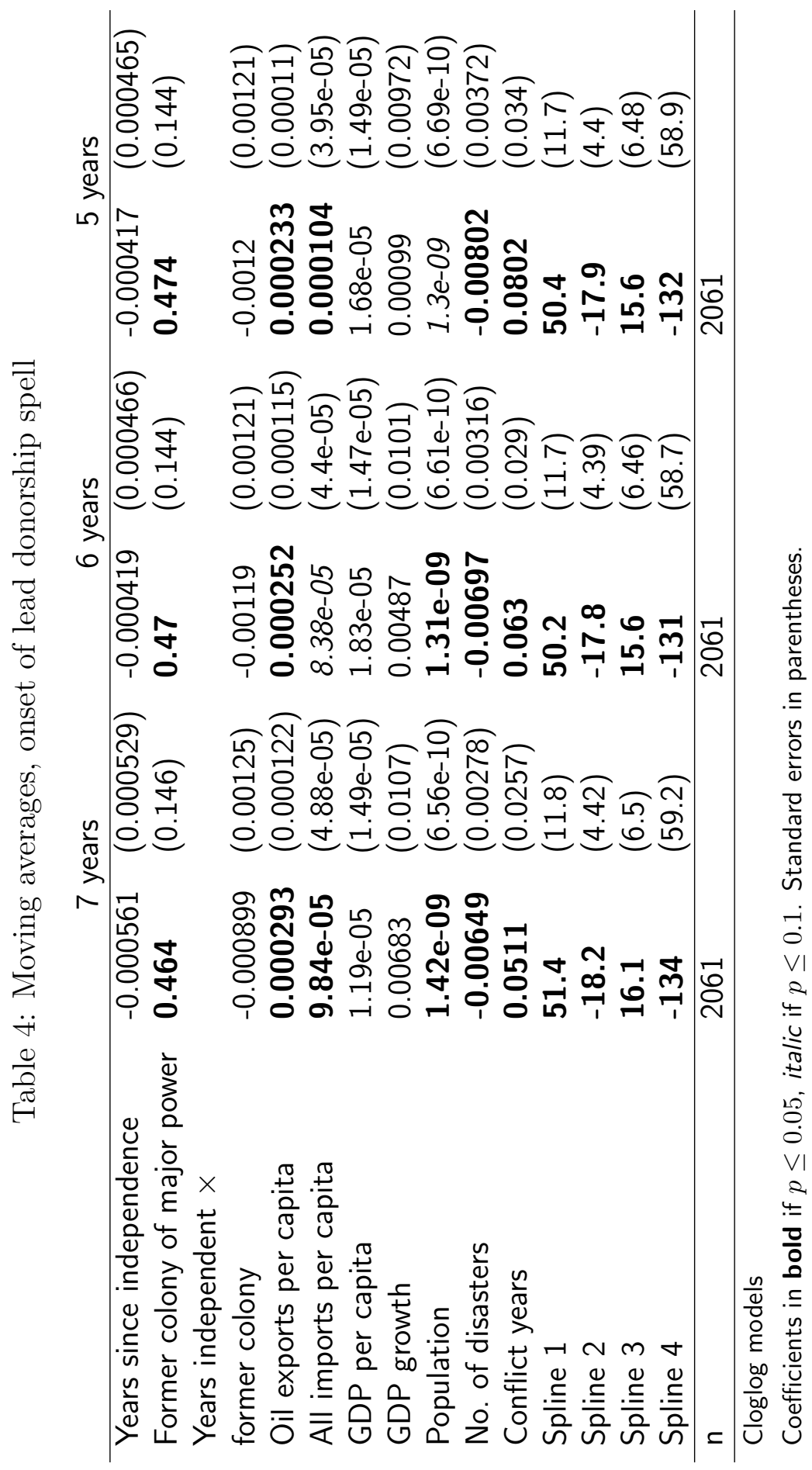




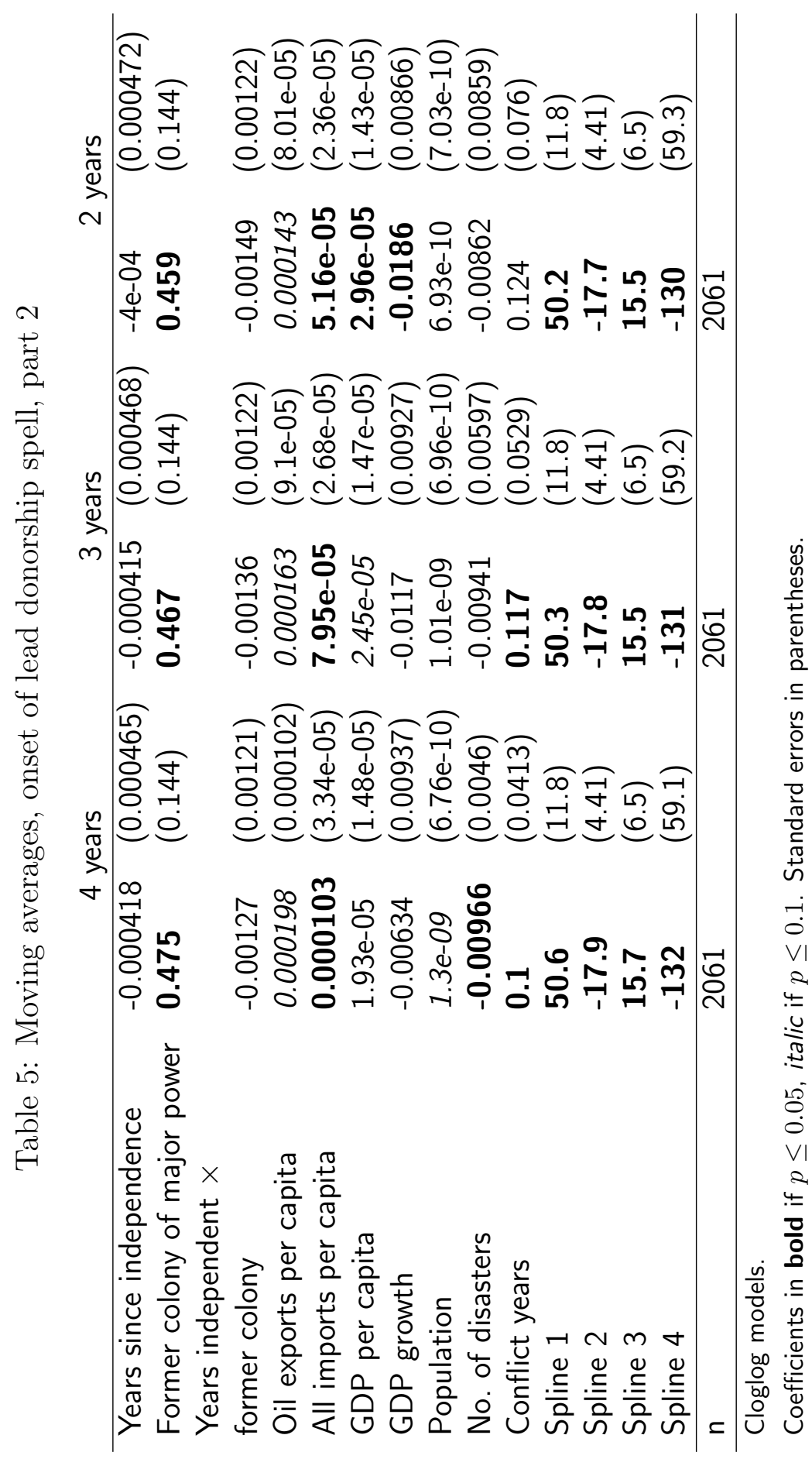




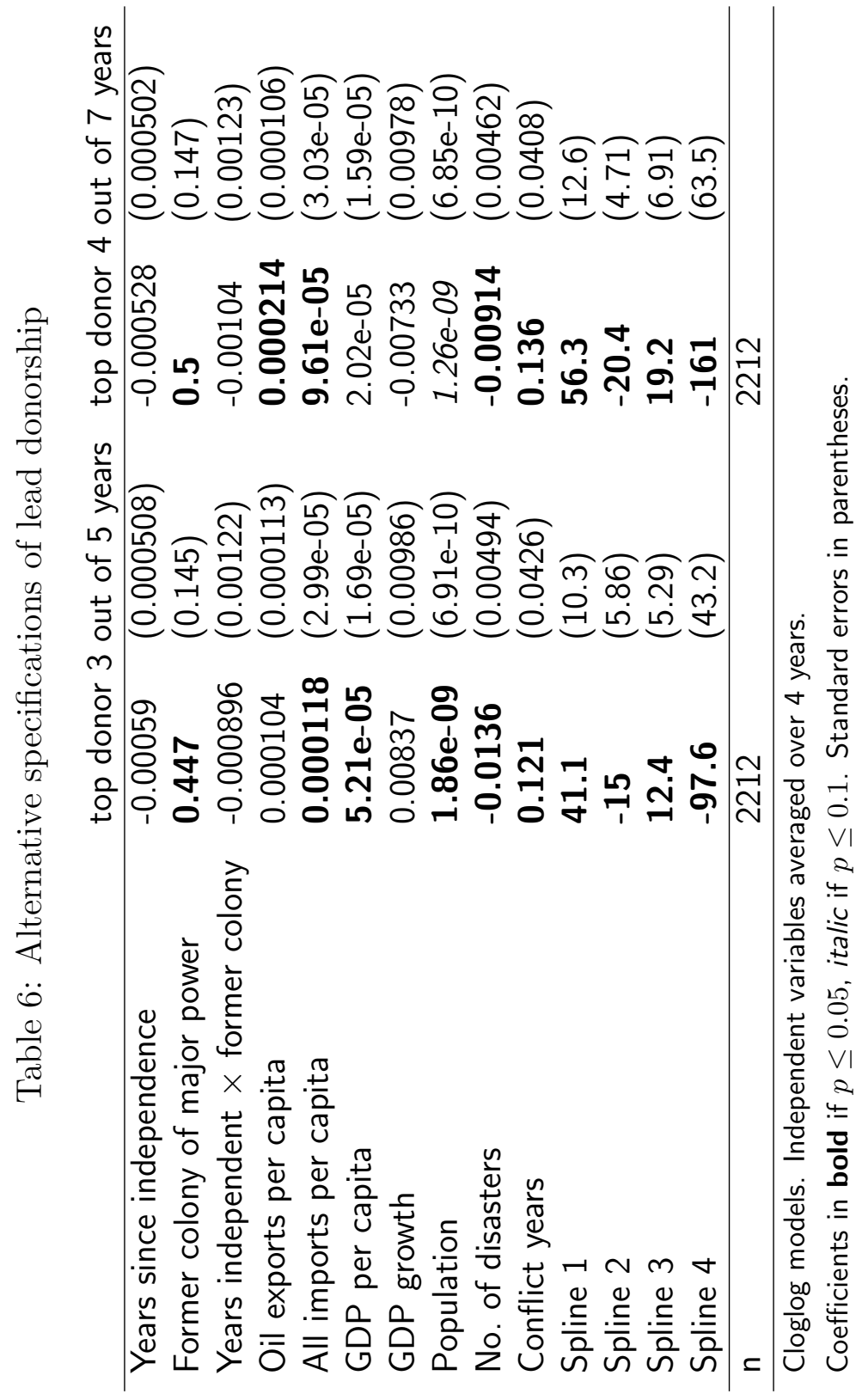




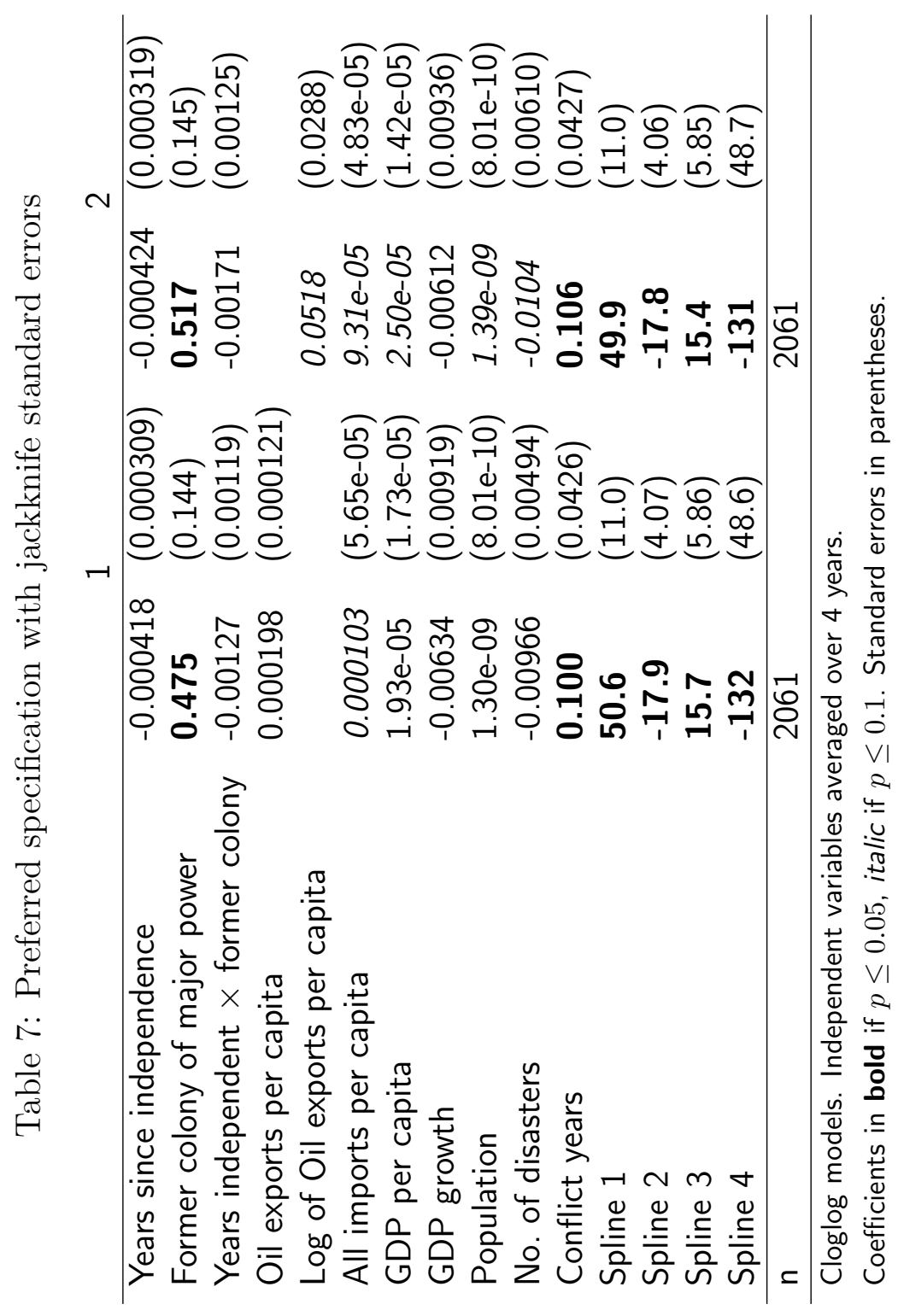

